\title{
Karl Johan Danell: La linguistique. Pratique et théorie. Lund: Stu- dentlitteratur, 1993
}

Karl Johan Danell, som er professor i fransk ved universitetet i Umeå, har skrevet denne bog for at give sine studerende og andre en introduktion til lingvistisk metode samt til grundlæggende lingvistiske begreber.

KJD's mål er at gøre de studerende bevidste over for sproglige problemer, så de søger løsninger og får brug for teorierne - eller med andre ord får lyst til at beskæftige sig med lingvistik. Han tager derfor læserne ved hånden og fører dem gennem hele den lingvistiske proces: Først formulerer han tre konkrete sproglige problemer med stigende kompleksitet, nemlig valget mellem de to ord an/année, visse aspekter af konstruktionerne faire faire quelque chose à quelqu'un/laisser faire quelque chose à quelqu'un og endelig forskellen mellem pas de vin/pas du vin; dernæst redegør han for de begreber og teorier, som synes at kunne anvendes til en løsning af disse problemer.

Bogen er tænkt som et supplement til de traditionelle grammatikker og lingvistiske værker, som KJD kritiserer for ofte blot at indeholde lange opremsninger af termer, begreber og lingvistiske skoler. Han mener, at der mangler pædagogisk orienterede værker, som giver de studerende mulighed for selv at afprøve teorierne som redskaber til analyse af sproglige problemer, i stedet for at de blot får præsenteret færdige løsninger. $\mathrm{Og}$ det er netop denne mangel, som han med nærværende bog søger at afhjælpe.

Ud fra et pædagogisk synspunkt må KJD's kritik af den traditionelle lingvistiske litteratur siges at være fuldt ud berettiget. Lingvistiske artikler og monografiske værker, som i reglen er skrevet for lingvister (dvs. for fagfolk), beskriver ikke de anvendte metoder i pædagogisk form, og grammatikkerne fokuserer i højere grad på analyseresultaterne end på selve metoden. Hertil kommer, at selvom enhver grammatiklærer vel nok præsenterer sine studerende for grammatiske øvelser, så er formålet nok snarere at checke, at de kan applicere grammatikkens "facitliste" rigtigt, end at formidle kendskab til lingvistisk metode. Denne mangel i den lingvistiske litteratur - og altså sandsynligvis også i sprogundervisningen - udgør et generelt problem, da glæden ved selv at løse et specifikt sprogligt problem (hvilket jo kræver kendskab til metoden) og især lysten til problemløsning, som bekendt, er en vigtig motiverende faktor i enhver indlæringsproces. Mere specifikt udgør manglen her i Danmark et - endog akut - problem i forbindelse med etableringen af den nye ph.d.uddannelse. Skal man i uddannelserne skabe forudsætninger og interesse for forskning i sprog, er det nemlig absolut nødvendigt, at der formidles en indsigt i og forståelse for lingvistisk metode.

En anden ting er, at man i de senere år har satset på forskningsbaseret undervisning på de højere læreanstalter. Det har bl.a. givet sig udslag i, at der så at 
sige udelukkende ansættes forskere i undervisningsstillinger. Baggrunden herfor må vel være, at forskeren forventes at have - og kunne formidle - et bredt kendskab til diverse lingvistiske teorier og til lingvistisk metode. Men for på mere systematisk vis at kunne formidle kendskab til lingvistisk metode er det nødvendigt, at der også findes egnet materiale til formålet. Det synes desværre generelt ikke at være tilfældet. Med denne bog er der imidlertid nu taget fat på udviklingen af materiale, som kan være med til at styrke forbindelsen mellem forskning og undervisning.

Bogen er udtryk for metodisk nytænkning, og KJD opfylder på glimrende vis sit mål. Med sin solide baggrund i såvel forskning som undervisning formår han på en klar og letforståelig måde at vise, hvordan lingvisten tager fat på og arbejder med et sprogligt problem, samtidig med at han med udgangspunkt i det empiriske materiale fører læseren godt rundt i den moderne lingvistik.

Enhver form for nytænkning fører dog næsten automatisk en række problemer med sig. KJD har i hovedsagen løst disse med held, men som det fremgår af det følgende, er der dog enkelte kritikpunkter.

Bogen består af fire kapitler: kapitel 1, som indeholder en generel introduktion til lingvistikken, og kapitlerne 2-4, hvor de tre ovennævnte sproglige problemer behandles. Hvert kapitel afsluttes med en sammenfatning af de behandlede termer og begreber. Endelig findes der sidst i bogen en oversigt over udvalgt litteratur.

I kapitel 1 præsenteres lingvistikkens formål, dens fremtidige opgaver og dens hoveddiscipliner. Desuden gives der en kort redegørelse for en række lingvistiske termer og begreber.

Lingvistikken har til formål at "dresser l'inventaire de tous les « objets » dont une langue est composée, ainsi que celui de toutes les règles qui gouvernent le fonctionnement de ces objets" (p. 12), og forfatteren peger på, at den som sådan stadig har mange opgaver at løse, herunder at:

- forbedre ordbøger og grammatikker,

- beskrive sprogvarianter og sprogets dynamik,

- skabe redskaber til at behandle specifikke sproglige problemer,

- give større forståelse af filosofiske og psykologiske spørgsmål; og at den herudover har en række praktiske anvendelser, f.eks. i forbindelse med udvikling af hjælpemidler til døve og af automatisk oversættelse.

Kapitlet afsluttes med en opdeling af lingvistikken i fem discipliner: fonetik-fonologi, morfologi, leksikologi, syntaks og semantik-pragmatik. Det kan her undre, at KJD i en præsentation af de forskellige forskningsområder fremstiller semantik og pragmatik som én disciplin, da pragmatikken interesserer sig for, hvordan sproget bruges, for sproget som redskab og for dem, der 
bruger dette redskab. Pragmatikken er således ikke nødvendigvis knyttet sammen med semantikken - omend grænsen mellem de to områder stadig diskuteres. Noget andet er, at man i konkret analyse ofte anvender begreber fra flere discipliner. I forbindelse med analysen af pas de vin/pas du vin (p. $101 \mathrm{ff}$ ) anvender KJD begreber fra såvel semantikken som pragmatikken, men han synes altså allerede i præsentationen af de enkelte discipliner at foregribe denne fremgangsmåde.

I kapitel 2 tager KJD udgangspunkt i valget mellem an/année. Først undersøges de to ords betydning for at finde ud af, om de er synonyme. Der redegøres for Saussures beskrivelse af det sproglige tegn, herunder begreberne "signifiant", "signifié" og referent, og for de begreber, som kan defineres med udgangspunkt i det sproglige tegn: synonomi, homonymi, polysemi, hyponomi, hyperonymi og antonymi, samt for forskellige måder, hvorpå der dannes nye tegn. Dernæst behandles semantiske træk, sandhedsbetingelser og endelig stil og konnotation, som ikke synes at influere på sandhedsbetingelserne.

Anvendelsen af det upræcise begreb stil er ikke uproblematisk, hvilket forfatteren selv gør opmærksom på. Han siger således, at der mellem an og année kan være stilistiske forskelle, men tilføjer "si l'on arrive à préciser la notion de style" (p. 21). Herefter behandles stil dog som et problemløst begreb, og der skelnes ligesom i mange traditionelle grammatikker mellem "style élevé", "style familier" og "style populaire" uden nærmere præcisering (p. 29). Som anvendt af KJD er stil generelt ikke et begreb, der opereres med inden for den moderne lingvistik, hvilket nok netop skyldes, at det ikke har været muligt at præcisere endsige definere begrebet. I sprogbrugsanalyser, herunder fagsprogsanalyser, anvendes termen undertiden, men her forstået som et udtryk for frekvensen af bestemte sproglige fænomener. Mere generelt behandles sprogbrugsvariationer nu - mere nuanceret - i form af genreanalyser mv. inden for pragmatikken. KJD, der som nævnt ovenfor ikke betragter pragmatikken som en selvstændig disciplin, men kun som et delelement i en disciplin, der benævnes semantik-pragmatik, ser imidlertid bort fra dette aspekt af pragmatikken.

KJD konkluderer, at der ikke kan påvises en semantisk forskel mellem an og année, og vælger derfor at undersøge, om der kan findes en syntaktisk forklaring på anvendelsen af de to ord. Dette bringer ham ind på den generative grammatiks analysemodel, hvor han redegør for regler for sætningsstrukturer, transformationer samt dybde- og overfladestrukturer. Efter denne præsentation af den generative grammatik, konkluderer KJD dog, at “il n'est pas très utile de se servir d'un système très formalisé quand on cherche à résoudre un problème « concret » comme celui du choix entre an et année (...). 
Au contraire, on risque de consacrer trop d'efforts aux aspects purement formels, et d'oublier un peu les questions de fond" (p. 38).

KJD vælger derfor en mere "praktisk" tilgangsvinkel, nemlig at tage udgangspunkt i en analyse af et konkret eksempelmateriale. Dette bringer ham ind på en diskussion af det empiriske grundlag, hvor bl.a. informantundersøgelser og tekstkorpora behandles. Der gøres opmærksom på forskellige problemer forbundet med anvendelsen af informanter, herunder på forskellen mellem disses bevidste og ubevidste kendskab til deres modersmål og på begrebet idiolekt. I diskussionen af tekstkorpora, skelnes der mellem typer og okkurens, og forfatteren berører ligeledes spørgsmålet om korpus' repræsentativitet. Til spørgsmålet om, hvorvidt et givent korpus er repræsentativt, siger KJD blot: "on peut toujours répondre que les résultats obtenus reflètent justement la langue telle qu'elle se présente dans les matériaux réunis.” (p. 41). KJD tager hermed afstand fra diskussionen om korpus' repræsentativitet, som hærgede de første begejstrede "korpusår" og endog førte til etablering af begrebet korpuslingvistik som en selvstændig videnskab. Problemet i forbindelse med begrebet repræsentativitet er, at man i statistisk forstand kun kan tale om en delmængdes repræsentativitet, hvis man kan definere den grundmængde, hvorfra delmængden er taget, men at det i lingvistiske undersøgelser i reglen netop ikke er muligt at definere denne grundmængde. Ofte kan man højst søge at danne sig et subjektivt skøn over grundmængden. Spørgsmålet er så, om man helt skal renoncere over for diskussionen af korpus' status i forhold til det omgivende sprog og, som KJD, nøjes med at konkludere, at analyseresultaterne afspejler sproget, således som det repræsenteres i korpus. Det er naturligvis den konklusion, man i sidste instans må drage. Det forekommer dog rimeligt alligevel at gøre sig nogle overvejelser om, hvorvidt den sprogbrug, som er repræsenteret i korpus, udgør en pålidelig genspejling af sprogbrugen også uden for korpus. Da bogen jo netop fokuserer på lingvistisk metode, kunne denne problematik efter min mening have fortjent en mere indgående behandling.

Ser man på de senere års diskussion af tekstkorpora, finder man en opblødning af begrebet repræsentativitet, idet mange går bort fra den strengt statistiske opfattelse heraf og over til snarere at opfatte ordet i dets mere almene betydning. Hvordan kan man så tilstræbe, at korpus er repræsentativt (i ordets nye betydning) for så vidt angår de sproglige fænomener, der unders $\emptyset$ ges? Atkins (1992), som taler om "balanced" korpus, kommer med følgende forslag:

"At present, corpus 'balance' relies heavily on intuition (..). It is not our purpose to lay down a methodology for 'balancing' a corpus, for we believe that this is not something that can be done in advance of the corpus building process, if it can be done at all. Controlling the "balan- 
ce' of a corpus is something which may be undertaken only after the corpus (or at least an initial provisional corpus) has been built; it depends on feedback from the corpus users, who as they study the data will come to appreciate the strengths of the corpus and be aware of its specific weaknesses." (Atkins, 1992).

Kort sagt, etablering af korpus beror i vid udstrækning på intuition, og man kan ikke på forhånd vide, om et korpus er "balanced" eller repræsentativt. Det får man først en fornemmelse af ved anvendelse af korpus. Er der tegn på, at korpus ikke er repræsentativt, kan man søge at afhjælpe manglerne.

Det kan tilføjes, at man som en foreløbig test på, om et korpus er repræsentativt, kan undersøge, om man i korpus finder belæg for de gængse konstruktionstyper mv., som er nævnt i den lingvistiske litteratur. Gør man det, må man vel kunne antage, at korpus er repræsentativt for så vidt angår den pågældende konstruktion.

Til slut kan nævnes, at man savner en diskussion af forholdet mellem henholdsvis informantunders $\emptyset$ gelsen og tekstkorpuset. Det er jo netop vigtigt at gøre sig klart, at de to typer af empirisk materiale ikke erstatter, men supplerer hinanden, og at valget mellem dem afhænger af formålet. Medens korpus således kan anvendes til at illustrere det mulige, til at undersøge et fænomen i en kontekst og som kilde til inspiration, egner informantunders $\varnothing$ gelsen sig til at afprøve grænserne for det acceptable, til at finde frem til det umulige.

KJD vælger i sin analyse at anvende et korpus (LIBBEL), som indeholder 17 numre af avisen La Libre Belgique. Herfra viser han de første 40 eksempler med de to ord. Helt i bogens ånd vises eksemplerne uden forhåndssortering for at give læseren et indtryk af den situation, som lingvisten står i, når han tager fat på et sprogligt problem.

På basis af disse eksempler når KJD frem til følgende resultat:

On met an après un chiffre, année partout ailleurs.

Exceptions 1 : sans chiffre, an est possible dans l'an dernier, l'an prochain, l'an passé, au fil des ans, au cours des ans, mais année va aussi dans ces phrases.

Exception 2 : sans chiffre, an est seul permis dans le nouvel an, le jour de l'an, bon an mal an, 100 dollars par an, 100 dollars l'an, tous les ans.

Exceptions 3 : chiffre + année existe (surtout avec complément). Presque toujours an est alors aussi possible. Avec adjectif qualificatif épithéte (les 40 années sombres), an est exclu.

KJD når imidlertid ikke, som lovet i indledningen (p. 7), frem til dette resultat ad ren induktiv vej. Det faktum, at han netop vælger at tage udgangspunkt i +/tilstedeværelse af talord i sætningen (p. 45), afslører, at han er påvirket af teo- 
rien. En analyse af eksempelmaterialet viser nemlig, at en række andre faktorer, heriblandt determination, kunne være relevante at tage i betragtning. Det viser sig således f.eks., at année er særlig hyppig i forbindelse med demonstrative artikler (Mais cette année, l'oeuvre de son grand-père passera dans le domaine public).

I kapitel tre behandles forskellige aspekter af faire, laisser, voir etc. + infinitiv.

Kapitlet indledes med en kort gennemgang af den traditionelle grammatiks beskrivelse af den egentlige kausative konstruktion med sammensat verbal, f.eks. On a fait boire le vin à Paul. KJD analyserer derefter konstruktionen med udgangspunkt i den generative grammatik og kommer her ind på rekursivitet, forholdet mellem generative regler og "phrases figées" samt begreberne kompetens og performans. Dernæst undersøges regler for subkategorisering samt ændringer, som fremkommer ved transformationer (permutation, addition og sletning). Endelig diskuteres problemer i forbindelse med verifikation af den generative model. KJD når herefter frem til følgende konklusion: "je ne trouve pas la grammaire générative très utile en pratique pour résoudre les problèmes linguistiques les plus intéressants ou les plus «immédiats ». S’il en est ainsi, c'est en partie parce que je trouve que la formulation de toutes ses règles compliquées risquent d'obscurcir, plutôt que d'éclaircir, les faits observés, les critères et les rapports pertinents.” (p. 73). Han tilføjer dog: “ Mais c'est sans doute une question de goût” (p. 73). I forordet til bogen anfører KJD, at fremstillingens teoretiske udgangspunkt kan beskrives som en eklektisk og empirisk strukturalisme, men at der ligeledes er medtaget en diskussion af den generative grammatik (p. 7). I lyset af KJD's strukturalistiske fodfæste, er det da også klart, at den generative grammatik, med dens problematiske forhold til semantikken, ikke falder i god jord. Man kan så blot undre sig lidt over, at der alligevel er givet så relativt megen plads til diskussionen af den generative grammatik. KJD medgiver dog de generative grammatikere, at de har "formulé bon nombre de principes essentiels d'ordre théorique, et qui, même au cas où ils seraient faux, nous obligent à réfléchir et à préciser notre pensée sur les mécanismes de la langue” (p. 73) - så måske er dét grunden.

KJD behandler herefter valget mellem de to konstruktionstyper: Je laisse jouer les enfants (type 1) og Je laisse les enfants jouer (type 2), som begge er mulige ved verberne laisser, voir, entendre og enkelte andre verber, men ikke ved faire, der altid konstrueres som type 1. KJD vælger også her at tage udgangspunkt i et korpus. På basis af eksemplerne i korpus - som læseren opfordres til selv at analysere - konkluderer han, at type 1 er mere frekvent end type 2, og han gør opmærksom på, at dette er i modstrid med de oplysninger, der er at finde i grammatikkerne, herunder Pedersen et al. (1982), som anfører, at type 2 er langt almindeligere end type 1 . Han påpeger derfor, at man skal 
være kritisk over for "autoriteterne". Man kunne her tilføje, at det gælder alle autoriteter, inklusive nærværende bog, og at den foretagne opdeling af eksemplerne fra korpus i henholdsvis type 1, type 2 og en type, som ikke klart henhører under 1 eller 2 (f.eks. histoire de laisser croire et écrire que la situation politique est désespérée), jo afhænger af teorien. Og som det fremgår af Skårup (1994, 131-132) er der netop uenighed på dette punkt.

Med henblik på at finde frem til de faktorer, der påvirker valget mellem de to konstruktionstyper, diskuteres indflydelse fra tunge sætningselementer, kompletive OI (objekt for inf.) og SI (logisk subjekt for inf., defineret som det nominalled, "qui désigne celui qui effectue l'action exprimé par Inf.") (p. 92) samt kriterier til identifikation af "phrases figées". På basis af analysen af de viste eksempler konkluderer $\mathrm{KJD}$, at valget mellem de to konstruktioner afhænger af følgende fire faktorer:

Facteur 1: On tend à placer l'élément le plus lourd, ou le plus long, à la fin. Autrement dit,

un SI lourd favorise le Type 1 (l'ordre V1 Inf SI) un Inf lourd (à cause de ses compléments) favorise le Type 2 (l'ordre V1 SI Inf).

Facteur 2: Quand SI est une complétive en que, le Type 1 (V1 Inf SI) est obligatoire.

Exemple : Cela fait ${ }^{1}$ apparaître que ...

Facteur 3 : Le groupe laisser + verbe «psychologique » impose le Type 1. Exemple : Je le lui ai laissé croire ${ }^{2}$

Facteur 4 : Finalement il faut tenir compte des phrases figées, qui amènent régulièrement le Type 1.

Exemple : Il laisse faire les acteurs.

Herefter diskuteres kort visse termer og analyser i forbindelse med konstruktionen faire + infinitiv, herunder hvorvidt det er berettiget at anvende termen SI, når dette led på det syntaktiske plan kan være enten akkusativobjekt, dativobjekt eller agens. Ifølge KJD er anvendelsen af termen SI berettiget, da dette led

1 Der må være tale om en lapsus, når der som eksempel anføres: Cela fait apparaître que ... (p. 91). Der må skulle stå Cela laisse apparaître que ..., da verbet faire + inf. som nævnt altid konstrueres som type 1.

2 Svarende til f.eks. : J'ai laissé croire à Paul que.. Derimod er *J'ai laissé Paul croire que - *Je l'ai laissé le croire ikke mulig. 
i reglen repræsenterer samme semantiske rolle (kasusrolle) ${ }^{3}$. Til illustration heraf gives følgende eksempler (p. 92): Je fais dessiner Paul, Je fais dessiner un cercle à Paul, Je fais dessiner un cercle par Paul, hvor Paul ifølge forfatteren har samme semantiske rolle ${ }^{4}$.

KJD er lidt uklar i sin beskrivelse af forholdet mellem det logiske subjekt for infinitiven og de semantiske roller. Uklarheden skyldes primært et definitorisk problem i forbindelse med SI. Som nævnt defineres det logiske subjekt nemlig i forhold til infinitiven udelukkende semantisk som "la phrase nominale qui désigne celui qui effectue l'action exprimé par Inf". Som følge heraf er det yderst vanskeligt at skelne mellem henholdsvis SI og den semantiske rolle AGENT, der defineres som "celui qui agit (ou qui effectue l'action dénotée par le verbe)" (p. 93). Problemet kunne være undgået, hvis KJD i overensstemmelse med traditionen havde defineret SI som et led, der repræsenterer såvel nogle syntaktiske (transformationelle) som nogle semantiske relationer, og hvis han samtidig havde gjort opmærksom på, at "effectuer l'action" derfor skal forstås i mere abstrakt forstand i forbindelse med det logiske subjekt end ved de semantiske roller.

I kapitel fire behandles valget mellem pas de vin/pas du vin, og der tages udgangspunkt i variationen mellem fuld delingsartikel $d u$, de la, des og reduceret delingsartikel i benægtede sætninger.

KJD undersøger, hvilke negationer og syntaktiske strukturer, der synes at medføre anvendelse af reduceret delingsartikel. I denne forbindelse konsulteres de gængse grammatikker, men KJD må konstatere, at der findes en del eksempler, som anvendes med fuld delingsartikel, selvom de i grammatikkerne nævnte betingelser for reduceret delingsartikel er opfyldt.

KJD vælger derfor at unders $\emptyset$ ge problemet mere systematisk. Til dette formål tager han udgangspunkt i 50 eksempler fra LIBBEL og 12 numre af den belgiske avis Le Soir. Herefter unders $\emptyset$ ger han en mere detaljeret grammatik for at se dennes forklaring på forskellen mellem pas de/pas du vin. Hermed kommer han ind på begreber som negationens scope og eksistens. For at præcisere disse begreber og dermed gøre dem mere operative vælger KJD at anvende forskellige tests, herunder parafrase. Han undlader imidlertid at gøre opmærksom på de overvejelser, som man bør gøre sig i forbindelse med anvendelse af tests generelt (se f.eks. Nølke 1994, 217 ff.). Det er lidt synd, da anvendelse af tests jo netop udgør et vigtigt element i den lingvistiske metode. I forbindelse med de nævnte tests redegøres der for centrale begreber inden for

3 Der tænkes her tydeligvis på kasusrollen AGENT.

4 KJD synes at overse, at sætningen Je fais dessiner Paul er dobbelttydig. Paul kan opfattes enten som "celui qui agit" eller som "celui qui est directement touché par l'action". (Se p. 93). 
prædikatslogikken, herunder prædikater, argumenter og operatorer. Da disse begreber imidlertid ikke umiddelbart synes at kunne anvendes, foretages en semantisk-pragmatisk analyse af nægtelsen, og i denne forbindelse diskuteres en række vigtige begreber inden for pragmatikken, såsom inferens, implikation, præsupposition, implikatur og tema/rema.

KJD må konstatere, at han ikke har fundet en tilfredsstillende forklaring på anvendelsen af henholdsvis fuld og reduceret delingsartikel, og han sammenligner sin bog med en kriminalroman, hvor sidste side mangler:

“Je ne sais si j'ose avouer la vérité :

Si on lit un roman policier qui commence par un meurtre, on s'attend à voir la solution du crime à la dernière page du livre. Or, je dois reconnaitre ici que le problème de la concurrence PAS DE /PAS DU n'est pas resolu (ou du moins pas aussi clairement que an/année et laisser Inf SI/ laisser SI Inf que nous avons traités dans les chapitres précédents). Donc, il faut plutôt regarder le présent texte comme un roman policier où la dernière page manque." (p. 146).

Det er uden tvivl lykkedes KJD at opfylde sit mål, nemlig at gøre læseren bevidst over for sproglige problemer og give ham/hende lyst til selv at søge løsninger og anvende teorierne. Den pædagogiske fremstillingsmåde og den trinvise opbygning kombineret med eksempelmaterialet samt en række øvelser gør, at man som læser får såvel lyst til som mulighed for at deltage aktivt $\mathrm{i}$ opklaringen af de tre mysterier. Selvom KJD undskyldende gør opmærksom på, at sidste side mangler, så betragter jeg det som en fordel: Det viser med al tydelighed lingvisten i arbejde, midt i processen. KJD har da også givet læseren sagens akter, så han/hun på egen hånd kan fortsætte opklaringsarbejdet.

Man kommer i bogen vidt omkring i den moderne lingvistik. KJD viser et bredt og grundigt kendskab til den moderne lingvistik, og han formår at formidle de lingvistiske begreber og teorier på en pædagogisk måde og i et klart og letforståeligt sprog. Man kunne dog have ønsket, at forfatteren havde brugt mindre plads på den generative grammatik, som med al tydelighed ikke falder i hans smag, og i stedet havde anvendt pladsen til en mere indgående diskussion af de metodiske problemer, herunder problemer i forbindelse med korpora og informantundersøgelser samt med anvendelse af tests.

Det er med denne bog lykkedes Karl Johan Danell at udfylde et hul i den lingvistiske litteratur, og bogen kan varmt anbefales til brug i franskundervisningen på de højere læreanstalter samt til nye ph.d.-studerende.

\section{Litteratur}

Atkins Sue; Jeremy Clear \& Nicholas Ostler: Corpus Design Criteria, in: Literary and Linguistic Computing, vol. 7 No 1, 1992: 1-16. 
Nølke, Henning (1994): Linguistique modulaire: de la forme au sens. Louvain: Peeters. Skårup, Povl: Compte rendu: Karl Johan Danell: La linguistique. Pratique et théorie, in: Revue Romane, vol. 29 No 1, 1994: 131-132.

Kirsten Wølch Rasmussen

\section{Giovanni Mafera, Carla Avanza Juul Madsen \& Henning Juul Madsen: Gyldendals røde ordbøger Dansk-Italiensk. Gyldendal, 1993}

Nærværende ordbog er et længe savnet bidrag til rækken af røde ordbøger og er som sådan en bilingval sprogordbog. For at anskueliggøre ventetiden kan det nævnes at 2. udgave af Gyldendals røde italiensk-dansk af samme forfattere udkom i 1980, og at dette er den første større dansk-italienske ordbog siden Berlingske Forlags fra 1959, som sidst er revideret grundigt i 1968 (Høybye og Mengel, 1968) og senere overtaget af Munksgaard, som siden har udgivet den uden væsentlige ændringer.

Ordbogen består af et dansk forord ( $1 / 2$ side $)$, et italiensk forord $(1 / 2$ side $)$, et afsnit om ordbogens anvendelse ( $41 / 2$ side), forkortelsesliste ( 3 sider), den alfabetiske ordliste (762 sider), to lister over uregelmæssige eller svære verber $\mathrm{i}$ hhv. italiensk (11 sider) og dansk $\left(2 \frac{1}{2}\right.$ side) og disses bøjning.

Forordet omtaler nødvendigheden af opofrelser fra forlag og forfatteres side p.g.a. det lille marked for en sådan ordbog, hvilket formentlig skal tolkes derhen at forfatterne i høj grad har arbejdet gratis, og forlaget er i tvivl om, hvorvidt trykkeomkostningerne kan dækkes. I betragtning af at der altså er tale om et con amore-projekt må man sige at der er gjort et ganske godt stykke arbejde, og det kan derfor synes urimeligt at gå så meget i detaljer som det er tilfældet i det følgende. Lad det derfor være sagt med det samme: Denne anmeldelse bør betragtes som en udpegning af områder, der bør opprioriteres ved fremtidige udgaver, snarere end som en kritik af det store arbejde, der vitterligt er gjort fra forfatternes side.

Ordbogens målgruppe er uafgrænset bortset fra nationalitet: Af det italienske forord fremgår det, at den primært henvender sig til danskere, men kan anvendes passivt af italienere (til oversættelse fra dansk eller ved læsning af danske tekster). Af hensyn til de italienske brugere er der medtaget oplysninger om visse danske verbers former samt nogle semantiske oplysninger, der er overflødige for danske brugere. Man kan således udlede, at ordbogen primært er beregnet til anvendelse ved oversættelse til italiensk, altså som aktiv ordbog.

Den dækker primært alment sprog, men der er taget ganske mange fagudtryk fra mange områder med. Fagudtrykkene er desværre ret tilfældigt udvalgt, 